\title{
The role of mantle plumes in the development of continental-scale drainage patterns: The southern African example revisited
}

\author{
Andy Moore \\ Somabula Explorations (Pvt.) Ltd, Box CH 399, Chisipite, Harare, Zimbabwe \\ email: andymoor@africaonline.co.zw \\ Tom Blenkinsop \\ Department of Geology, University of Zimbabwe, P.O. Box MP 167, Mount Pleasant, \\ Harare, Zimbabwe \\ Present address: School of Earth Sciences, James Cook University, \\ Townsville, QLD4811, Australia. \\ e-mail: Thomas.Blenkinsop@jcu.edu.au
}

\begin{abstract}
Mantle plumes that precede continental break-up have been postulated to exert a major influence on continental drainage patterns. In this model, a radial drainage develops away from the centre of the plumes, while failed arms of the associated rift system provide conduits for rivers from the continental interior towards the newly formed ocean. This paper summarises drainage evolution in southern Africa from the Permo-Carboniferous to the lower Cretaceous in order to test this model. A major reorganisation of the river system occurred at the time of eruption of the Karoo volcanics, or during subsequent fragmentation of Gondwana. The Karoo and Paraná Plumes imposed a first-order imprint on the drainage pattern. The superimposition of the Paraná plume pattern on the earlier Karoo plume drainage is responsible for the dominant eastward drainage system from the Early Cretaceous to the present-day. The post-Gondwana river network has been modified by at least three other major factors: structural controls, exhumed ancient land surfaces, and post-Gondwana epeirogenic flexing of the sub-continent and resulting river capture. Understanding the factors responsible for initiation and evolution of continental-scale drainage patterns has important economic implications - for example, the identification of primary sources of diamond placers.
\end{abstract}

\section{Introduction}

Mantle plumes rising beneath continents are considered to be responsible for domal uplift, flood basalt volcanism and ultimately rifting (White and McKenzie, 1989). Cox (1989) proposed that the uplift initiates a pattern of drainage away from the highest part of the dome (dome-flank river systems), while failed arms of the rift system should lead drainages towards the new ocean (rift-related river systems) (Figure 1). He based this model on the configuration of modern drainage in India, South America and southern Africa. This evidence has been criticized because it failed to take into account changes in drainage configuration since break-up of Gondwana (Summerfield, 1990).

Studies of palaeo-current directions in the Karoo sequence in southern Africa (e.g. Visser, 1987; Veevers et al., 1994) provide a framework for understanding drainage evolution prior to the disruption of Gondwana. Two recent studies (de Wit, 1999; Moore and Larkin, 2001) provide a broad outline of the lower Cretaceous drainage system of the sub-continent. This paper reviews the changes in drainage patterns in southern Africa prior to and immediately following the disruption of Gondwana. The lower Cretaceous (post-Gondwana) drainage system is then discussed within the framework of the domal uplifts related to the mantle plumes that are inferred to be responsible for the Jurassic Karoo and
Cretaceous Etendeka flood basalts in southern Africa, (e.g. White and McKenzie, (1989); Storey and Kyle, 1997; 1989; White, 1997) and their influence on drainage patterns, with the view to evaluating the model for drainage evolution proposed by Cox (1989). This study also has implications for the processes responsible for localizing mantle plumes.

\section{Karoo and Paraná plume-related domes}

Cox (1989) assumed that doming over the Karoo and Paraná Plumes corresponded to the mantle thermal anomalies postulated by White and McKenzie (1989). The latter were delineated on the basis of the surface outcrop of Karoo volcanic rocks, but omitted subcropping lavas. Figure 2 is a compilation of the distribution of surface and subcropping Karoo lavas, based on Marsh et al. (1997) with additional information from the 1:1 000000 Geological Map of Zimbabwe (1997). Included in Figure 2 is the major Botswana dyke swarm, described by Reeves (1978), and the extent of the mantle thermal anomalies associated with the Karoo and Paraná Plumes (White and McKenzie, 1989).

The extent of the Karoo Plume inferred by White and McKenzie does not include significant areas of exposed and subcropping Mesozoic Karoo lavas, including those near Mariental in southern Namibia. However, lava distribution is probably not a reliable indicator of plume 


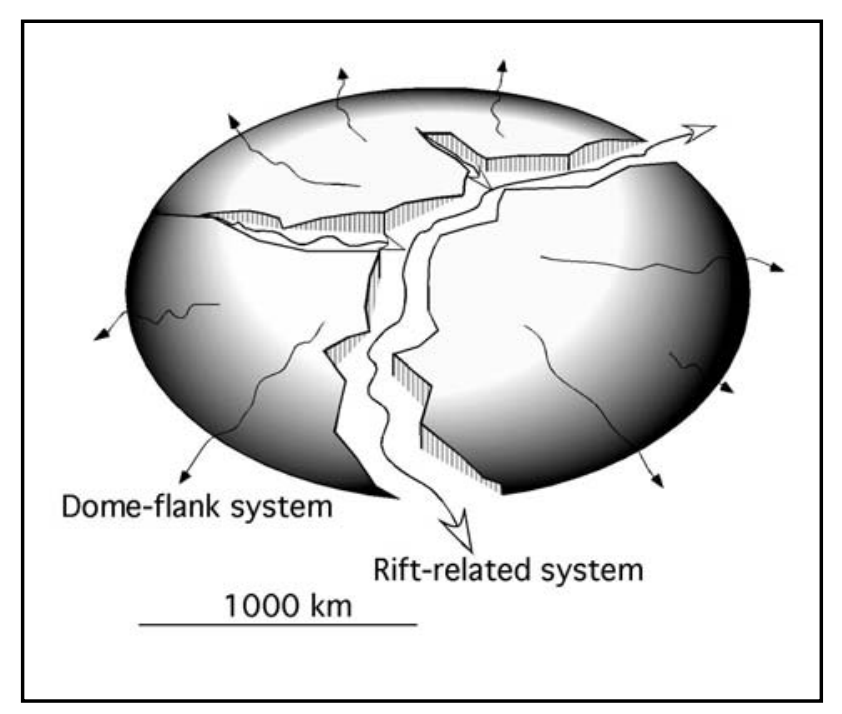

Figure 1. Distinction between centripetal drainage of the dome flank system (solid arrowheads) and the radial drainage of the riftrelated system (open arrowheads) (Cox 1989).

locations in view of the fact that flows may travel over distances on the order of hundreds of $\mathrm{km}$ (Swanson et al., 1975; White, 1997). Moreover, Cox (1992) has suggested that "local physical heterogeneities" in the crust may influence the location of volcanism above the plume head, while Ebinger and Sleep (1998) have proposed that melt may be channelled along the base of the lithosphere for a considerable distance from its source.

A number of possible sites for the centre of the Karoo Plume have been proposed. Earlier ideas are summarized in Cox (1992), while more recent concepts are discussed in Storey and Kyle (1997) and White (1997). All of these proposals envisage centres in the Nuanetsi area or along the Mozambique coast, and radii of the order of $1000 \mathrm{~km}$. A study of dyke distribution in southern Africa by Reeves (2000) provides a new perspective on this question. The densest concentration of dykes recognized by Reeves is in the vicinity of the junction of the Lebombo and Sabi Monoclines (Figure 2). This concentration is also at the convergence of three major trends of Karoo-age dykes. These are the west-northwest trending Botswana Dyke swarm, dated at $\sim 180$ Ma (Marsh et al., 1997), the approximately North-trending Rooi Rand Dykes, which intrude the Lebombo lavas ( 180 Ma: Armstrong et al., 1984; Marsh et al., 1997) and the east-northeast trending Limpopo swarm, which intrudes the Karoo Nuanetsi basalts. This dense concentration of dykes, as well as the convergence of the swarms, suggests a major focus of igneous activity. This is supported by the eastward thickening of the Karoo extrusive rocks from the interior of southern Africa towards the Lebombo, where they reach a thickness in excess of $13 \mathrm{~km}$ (Darracott and Kleywegt, 1974; Eales et al., 1984; White, 1997). This new evidence supports the early suggestion of Burke and Dewey (1973) that a major focus of volcanic activity was at one time centred at the intersection of the Lebombo and Sabi Monoclines in the Nuanetsi area (Figure 2).

The divergent views on the precise location of the Karoo Plume are not material to the evolution of the major southern African drainages on the scale considered in this study. The thermal effect of the plume would have produced a broad regional topographic high, with a centre somewhere in the area between Nuanetsi and the modern Mozambique coastline. The construction of a thick lava pile, and effects of crustal underplating (Cox, 1993; White, 1997), would have enhanced the elevation. The uplift linked to the thermal effects of the plume would be transient, but long-term uplift could be maintained by the addition of new igneous rocks to the crust, either as extrusive volcanics, or intrusives underplated at the base of the crust (Cox, 1993; White, 1997).

At the close of the Karoo volcanism, much of southern Africa was blanketed by a lava carapace (Cox, 1992; Marsh et al., 1997), which thinned towards the west (White, 1997). Regardless of the precise location of the plume head, according to the Cox hypothesis, a broad topographic high, resulting from the construction of a lava pile, with or without associated continental doming, would have been centred somewhere between Nuanetsi and the Mozambique coast. Given the anticipated low relief of the lava

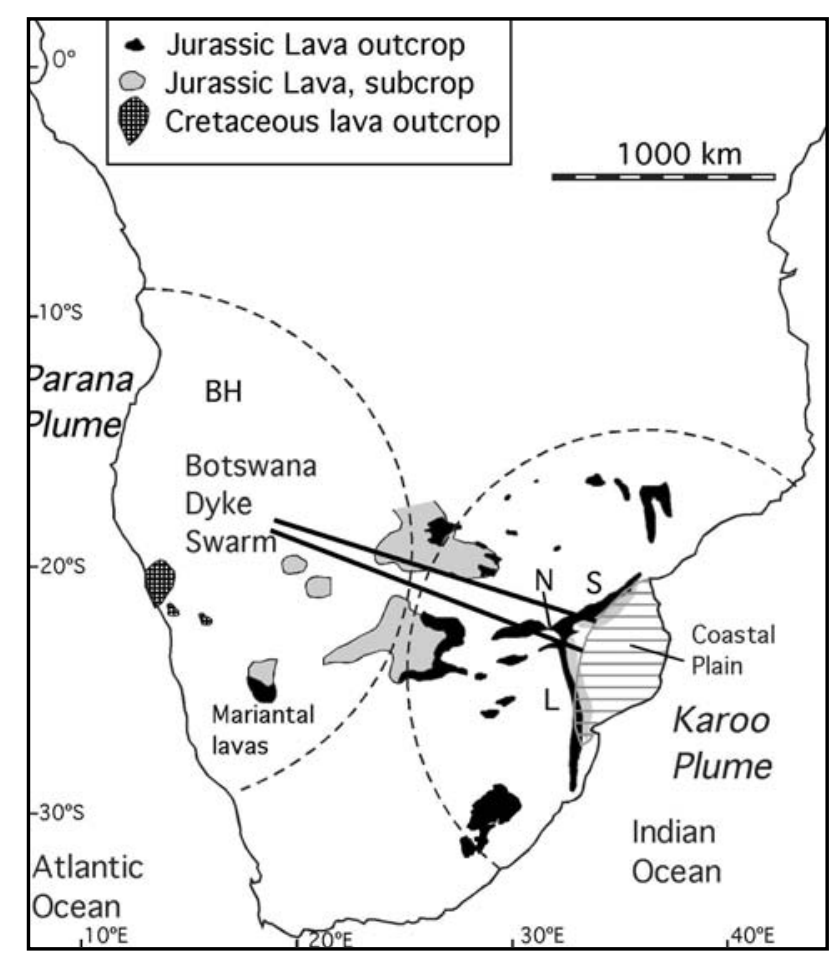

Figure 2. Location of outcrops and sub-outcrops of Karoo and Cretaceous lavas in southern Africa, and of the Botswana dyke swarm. Dashed lines show inferred extents of the Karoo and Paraná plume heads (White and McKenzie, 1989; Cox, 1989). $\mathrm{L}=$ Lebombo monocline; $\mathrm{S}=$ Sabi monocline; $\mathrm{N}=$ Nuanetsi; $\mathrm{BH}$ - Bié highlands. 




Figure 3. Carboniferous - earliest Permian glacial dispersion patterns in southern Africa (compiled from Visser, 1987; Veevers et al., 19942

carapace, there would have been an extensive regional slope away from this topographic high.

The size and location of the Paraná Plume is also subject to debate. White and McKenzie (1989) assumed that the Paraná and Etendeka volcanics were essentially contemporaneous, and related to a plume, with a radius of $\sim 1000 \mathrm{~km}$, centred a little to the north of the main Etendeka outcrop. However, more recent high precision ${ }^{40} \mathrm{Ar}-{ }^{39} \mathrm{Ar}$ dating demonstrates that the ages of the Paraná lavas decrease systematically from $\sim 137 \mathrm{Ma}$ at the extreme Northwest of the Paraná outcrop to $\sim 127 \mathrm{Ma}$ in the Southeast. The Etendeka lavas give ages of $\sim 130$ to $\sim 127 \mathrm{Ma}$, at the younger end of the range found in the Paraná lavas of South America (Turner et al., 1994; Stewart et al., 1996) (Figure 6). These data raise the question of whether this age progression reflects plate migration over a plume, or whether it reflects extensional tectonics. Stewart et al. (1996) favour the latter interpretation.

A different perspective is offered by Summerfield (1991), who proposed that rather than the broad Paraná dome envisaged by Cox (1989) there were two discrete smaller centres of uplift associated with the opening of the Atlantic. One was centred on the present outcrop of the Etendeka lavas, and the other on the Bié Highlands in southern Angola (Figure 2). No flood basalts occur in the latter area, but it is traversed by dolerite dykes of unspecified age (Instituto Geologico de Angola, 1:1 000000 Mineral Resources Map, 1998).
While Summerfield (1991) does not discuss the rationale for inferring two centres of uplift associated with the opening of the south Atlantic, this could account for the Bie high. O'Connor and le Roux (1992) offer possible support for this interpretation. These authors suggest that the Parana Plume is now reflected by the Tristan hot spot, with a radius of $250 \mathrm{~km}$, significantly smaller than that of the Lower Cretaceous plume inferred by White and McKenzie (1989).

However, there is an alternative possible explanation for the Bié highlands, as they are located to the south of a major graben, associated with a line of alkaline volcanic centres (White et al., 1995). Marsh (1973) suggested that these alkaline volcanics (and by implication, the graben) are the continental expression of a major transform faults associated with the opening of the Atlantic. He proposed that an alkaline igneous lineament in Brazil was related to the same transform fault.

Ages of $\sim 104 \mathrm{Ma}$ and $\sim 131 \mathrm{Ma}$ respectively have been reported for the Njoio and Tchivera nepheline syenites on the Angolan alkaline lineament (Allsopp and Hargraves, 1985). Those in Brazil, which Marsh (1973) suggests are related to the same transform fault, have $\mathrm{K}-\mathrm{Ar}$ ages ranging from $\sim 185$ to $\sim 82 \mathrm{Ma}$ (Sonaka and Garda, 1988).

Given the spread, and limited number, of age determinations for the Angolan alkaline lineament, and the wide range of ages in the inferred related Brazil 


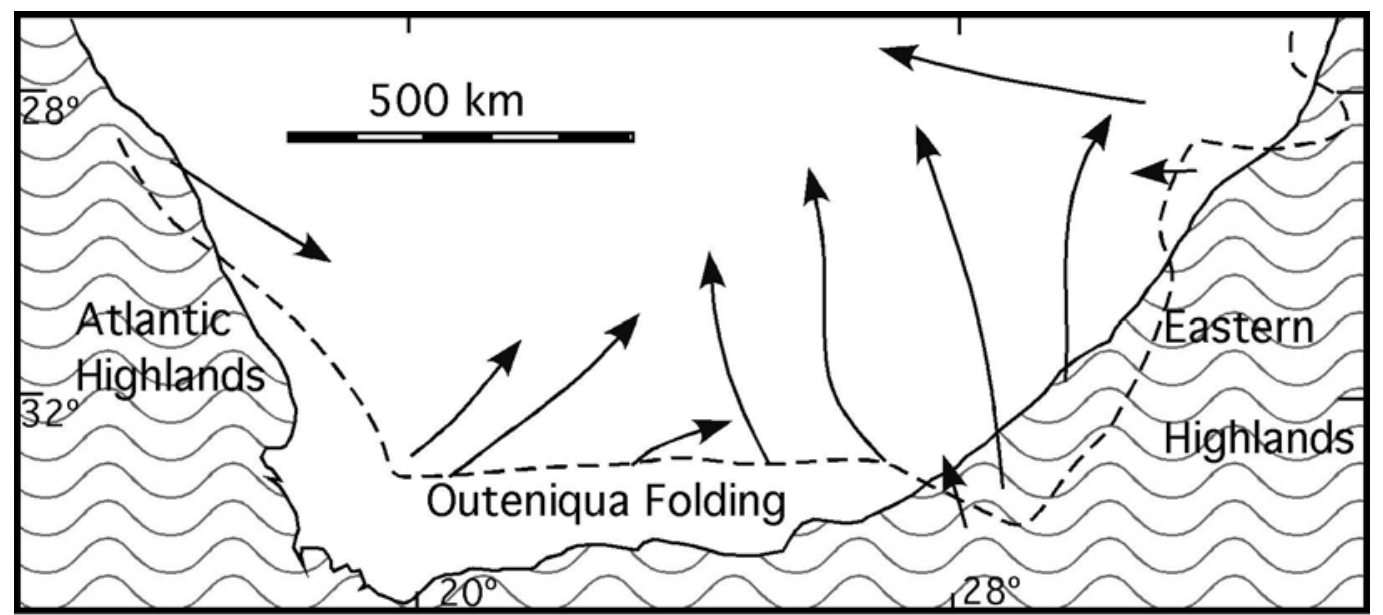

Figure 4. Late Permian - early Triassic (Beaufort Group) sediment dispersion patterns in southern Africa (after Veevers, et al., 1994). This broad pattern persisted to the deposition of the late Triassic Elliot formation of the Stormberg Group, which is separated from the Drakensberg volcanics by the aeolian Clarens Formation.

alkaline lineament, the timing of rifting in Angola, and thus of uplift of the Bié highlands remains conjectural. The spread of ages of the alkaline volcanics indicates that uplift may have been active at or prior to the opening of the Atlantic, but may post-date this event. Doming associated with the Paraná-Etendeka volcanism, as in the east of Angola, would have produced a broad topographic high. It seems likely that the Bié highlands formed by the development of a rift across this dome, but more work is needed to constrain the age of rifting. Given this uncertainty, and the absence of flood basalts in the Bié area, the simple case of a broad dome associated with the Paraná plume, following White and McKenzie (1989) and Cox (1989), is assumed in Figure 2. This simplification is not important in terms of the broad-scale interpretation of drainage evolution. However, it does have specific implications for understanding the evolution of the Cunene River, as discussed in a later section.

\section{Continental-scale drainage systems in southern} Africa from the Permian to the Lower Cretaceous

During lower Karoo times (Permo-Carboniferous), a belt of elevated ground, termed the Cargonian highlands, extended from southern Namibia to the east-northeast across southern Africa (Figure 3). The Karoo and Kalahari sedimentary basins were located to the south and north of this high ground respectively. The dominant glacial transport directions from the Cargonian highlands were to the south, southwest and west into the Karoo Basin, and to the west and northwest into the Kalahari Basin. The latter was also fed by glaciers rising off the Windhoek highlands, located to the north (Figure 3).

Late Permian-early Triassic uplift of the southern Cape fold belt strongly modified the palaeo-geography of southern Africa, initiating a northerly transport direction. Elevated ground to the west and east of the modern southern African coastline provided the headwaters for easterly and westerly transport components respectively (Figure 4). This general pattern persisted until the deposition of the late Triassic Elliot Formation of the Stormberg Group (Veevers and Powell, 1994). The latter is separated from the early Jurassic Karoo basalts by the aeolian Clarens Formation.

The configuration of drainage systems in southern Africa during the period following the infill of the Karoo Basin and the eruption of the Karoo lavas is conjectural. It is therefore not possible to establish whether relics of this drainage system are preserved today. However, the modern drainage system is clearly unrelated to the upper Karoo sediment dispersion patterns into the interior of the sub-continent.

Figure 5 summarizes the early Cretaceous continental-scale drainage systems in southern Africa based on the reconstructions of de Wit (1999) and Moore and Larkin (2001). (Except for the Karoo and Kalahari Rivers, discussed below, names of modern rivers are used for drainages). In the early Cretaceous, two major rivers (the Karoo and Kalahari) flowed into the Atlantic Ocean (de Wit, 1999). Three substantial rivers emptied into the Indian Ocean (Moore and Larkin, 2001). These are, from north to south, the Lower Zambezi, the Save and the Limpopo. The latter was by far the largest of these, with the southeast-flowing Cuando, Okavango and Upper Zambezi forming major headwaters. The Kafue and Luangwa were major southwest-flowing tributaries to the upper Zambezi.

\section{Relationship between plumes and drainage evolution}

In the early Cretaceous there appear to be only two major rivers which might be interpreted as dome-flank systems initiated by the Karoo Plume - the Kalahari and the Karoo Rivers recognized by de Wit (1999). The lower 


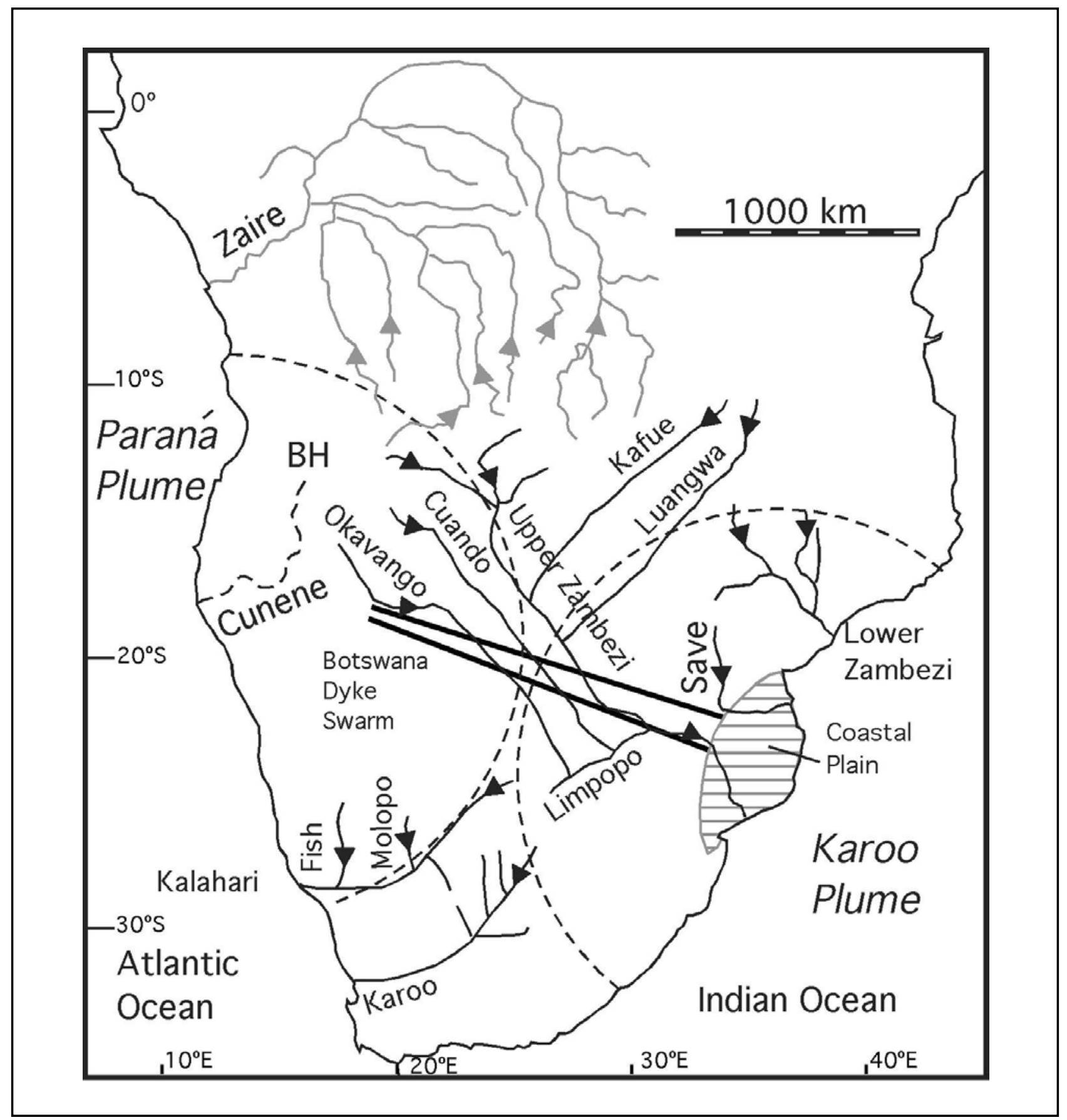

Figure 5. Early Cretaceous drainage system in south-central Africa based on the reconstructions of de Wit (1999) and Moore and Larkin (2001). Locations of Karoo and Paraná plumes and Botswana dyke swarm taken from Figure 2. BH - Bié highlands.

Limpopo and Save Rivers entered the low-lying Mozambique plain close to the intersection between the Botswana dyke swarm and the Lebombo and Save Monoclines (Figures 2 and 5). Reeves (1978) suggests that the Botswana dykes were emplaced along the failed arm of a triple junction. The lower Limpopo and Save Rivers could thus be viewed as rift-related drainages. The linear course of the upper Save flowed in a Karooage rifted basin. The course of the Lower Zambezi was also rift controlled (Nairn et al., 1991).

The southward flowing Fish and Molopo tributaries of the Kalahari River can be interpreted as examples of dome-flank drainages initiated by the Paraná Plume. Cox (1989) interpreted the southeast flowing Okavango, Cuango and Upper Zambezi headwaters as dome-flank drainages initiated by the Paraná Plume. However, the lines of these major former Limpopo tributaries do not form the radial pattern expected if controlled only by doming over the Paraná Plume. Rather, their long, straight and parallel courses point towards a strong structural control that is superimposed on the domeflank influence. Although not noted by Cox (1989), the south bank headwaters of the modern Congo River also drain away from the inferred dome over the Paraná 


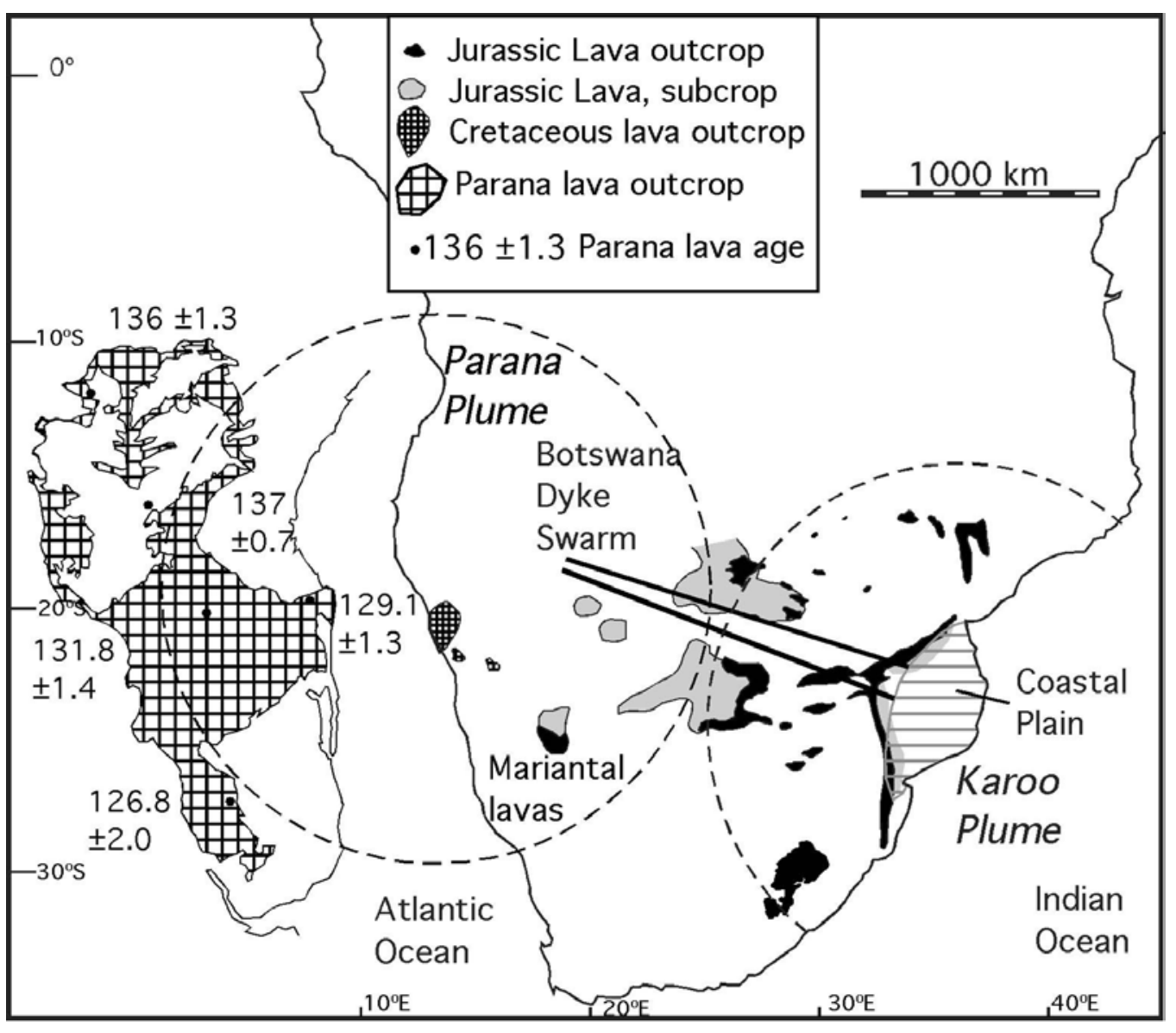

Figure 6. Pre-drift map of South America and southern Africa showing the distribution of the Jurassic Karoo and Cretaceous lavas and the Jurassic Botswana Dyke swarm. Selected ages for the Paraná and Etendeka lavas are from Stewart et al., 1996. Note that a projection of the line of the dyke swarm is oriented towards the focus of the earliest volcanic activity in South America.

Plume (Figure 3). While the Cretaceous configuration of this river system is unknown, the present-day pattern is consistent with an unmodified dome-flank system.

The Drakensberg volcanics associated with the Karoo Plume have an age of $\sim 183 \mathrm{Ma}$ (mid-Jurassic) (Marsh et al., 1997). The early Cretaceous ages of the Paraná and Etendeka lavas require that the associated plume was $\sim 40$ to $\sim 50$ Ma younger than the Karoo Plume. Earlier activity of the Karoo Plume is consistent with opening of the Indian Ocean before the Atlantic (Dingle et al., 1983). The regional slope away from the Etendeka high might therefore be expected to locally reverse the earlier slope initiated by the Karoo Plume. This effect would be enhanced by subsidence of the Mocambique plain by the early Cretaceous as a result of sediment loading (White, 1997). The early drainage pattern of southern Africa would thus be expected to reflect the interference between the Karoo and Paraná plumes, and their relative ages, as discussed below.

The Lower Cretaceous drainage system (Figure 5) is dominated by rivers that flowed towards the east coast. The only major west-flowing drainages in southern Africa in the Lower Cretaceous were the Karoo and Kalahari Rivers (de Wit, 1999). The dominantly east- flowing direction of the early Cretaceous drainage system accords with the younger age of the Paraná plume and doming event. This could also explain the striking absence of major westward drainage systems between the Kalahari (modern Orange River) and the Congo rivers. This pattern has persisted to the present day.

The model put forward by Cox (1989) therefore does appear to provide a broad, first-order framework for understanding the initiation of the post-Gondwana drainage system in southern Africa. In detail, the inferred plume-initiated drainage system has been influenced by a variety of additional factors. Thus, for example, the southwest-flowing Luangwa and Kafue Rivers are not readily explained in terms of either the Karoo or Paraná plumes (Figure 5). The former flows in a rifted-bound Karoo basin. The parallel course of the latter also strongly implies a structural control. These two rivers intersected the upper Zambezi at a high angle, which is typical of capture elbows. This raises the intriguing possibility that the courses of the Kafue and Luangwa may have originally continued further to the southwest prior to the drainage reorganisation linked to continental doming over the Paraná Plume. 
The modern-day Cunene, shown as a dashed line in Figure 5, is also not readily explained in terms of the model presented by Cox (1989). As the headwaters of this major river are located in the Bié highlands, its history must be related to the development of this topographic high. As noted earlier, this is not yet well constrained. Irrespective of the age of uplift of the Bié highlands, the lower Cunene exploits the trough between this high ground and the topographic high, which Cox (1989) ascribes to the Paraná Plume. Nevertheless, the modern Cunene may reflect additional geological controls. Wellington (1955) points out that the upper Cunene originally continued to the South, but was captured by the Lower Cunene. The latter river exploited a Permo-Carboniferous glacial valley, which was probably filled by Karoo sediments (Visser, 1987). Although the timing of the capture is not well constrained, lowering of base level associated with the opening of the Atlantic initiated a period of rapid erosion along the western margin of the sub-continent in the early Cretaceous (Brown et al. 1990). Stripping of the Karoo sediments, and exhumation of the glacial valley could in turn have lead to capture of the upper Cunene. This example demonstrates that exhumed topographies may lead to further deviations from the ideal domerelated drainage systems predicted by Cox (1989).

The drainage system of south-central Africa has been modified by a series of river captures since the lower Cretaceous, triggered by post-Gondwana epeirogenic uplift of the sub-continent (Moore, 1999; Moore and Larkin, 2001). Thus, the Upper Zambezi and Cuando, both former headwaters of the Limpopo, have been captured by the Lower Zambezi (Moore and Larkin 2001). However, many of the plume-related elements of the early drainage systems are preserved, such as the rift-related courses of the lower Zambezi, Save and Limpopo Rivers, and the dominant eastward drainage network.

\section{Relationship between the Karoo and Paraná plumes}

Figure 6 shows the distribution of Karoo and Cretaceous lavas in southern Africa and South America just prior to the opening of the Atlantic (data taken from Figure 2 and Stewart et al., 1996). An intriguing relationship brought to light by this figure is that the trend of the Botswana dyke swarm can be extrapolated towards the northern extremity of the Paraná volcanic rocks. Turner et al. (1994) and Stewart et al. (1996) demonstrate that this area formed the focus of the earliest Paraná volcanism, and that volcanic activity migrated to the southeast over the next 10 to $12 \mathrm{Ma}$. The trend of the Botswana dyke swarm towards the initial location of the Paraná volcanic rocks may be coincidental. However, this relationship raises the possibility that the line of weakness exploited by the Botswana dyke swarm could have influenced the position of the Paraná plume. Reeves (1978) interprets this line of weakness to reflect a failed arm of a triple junction linked to the opening of the Indian Ocean, which was in turn initiated by the Karoo Plume (Storey and Kyle, 1997). If so, the Karoo Plume may have indirectly influenced the geometry of the later dominant eastward drainage systems related to the Paraná Plume in southern Africa.

\section{Summary}

The evidence presented above suggests that the modern drainage system in southern Africa cannot be interpreted solely in terms of dome flank and rift-related systems as proposed by Cox (1989). Additional influences include structural controls, the imprint of exhumed surfaces, and processes of river capture. Some of these influences are illustrated in Figure 7. A further complication is introduced by the superimposition of plumes of different ages. This has resulted in a partial overprinting of the drainage system initiated by the Karoo Plume by that of

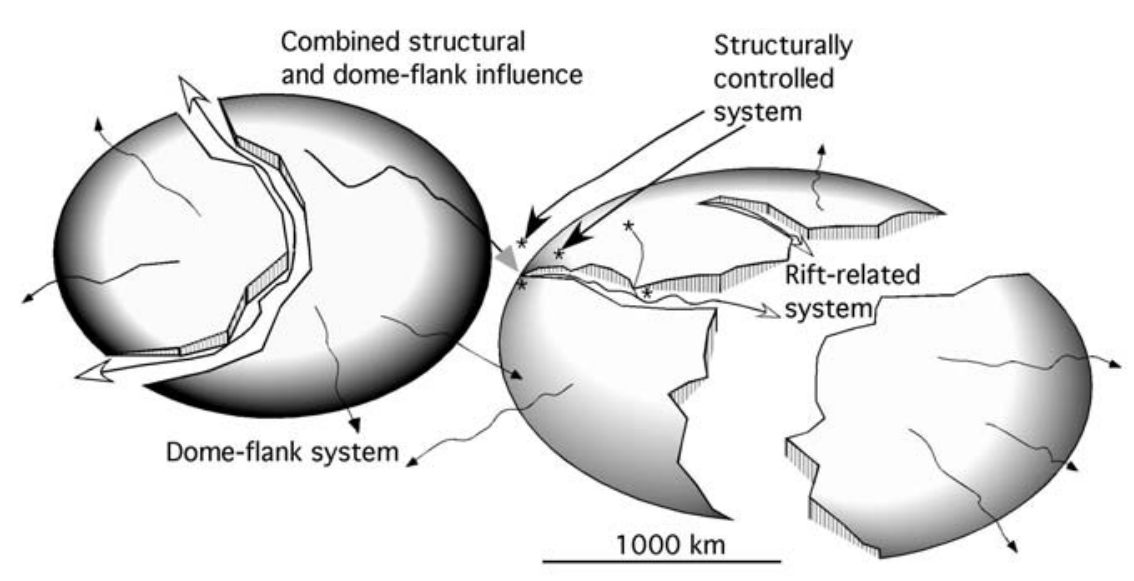

Figure 7. Superimposition of a younger plume (left hand side) and structural control on drainage. Structurally controlled drainage in solid barbed arrowhead. Note growth of rift-related drainages in the original plume (right hand side) and the possibility of river capture (*) as these systems grow. Gradient in shading indicates regional slope, which decreases in the original plume as it dies. This schematic diagram is based on the southern African example discussed in the text. 
the younger Paraná Plume. This accounts for the dominant eastward drainage pattern in southern Africa. These plume-related drainages were in turn superimposed on even earlier Gondwana river systems - for example, the Dry Harts, which is an exhumed Permo-Carboniferous glacial valley, that drained towards the major marine basin in the south of the subcontinent (du Toit, 1910). Seeing through the veil of such superimposed drainage systems has major economic implications for identifying the primary sources of unexplained alluvial diamond deposits (de Wit, 1999; Moore and Larkin, 2001).

The conclusions reached in this study underline Cox's farsighted appreciation of the link between theoretical igneous petrology and geomorphological processes. The approach used in this paper could be applied to the South American and Indian drainage systems used as examples by Cox (1989). This would allow further evaluation of the relative importance of plume-related as opposed to other controls on continental-scale drainage evolution.

\section{Acknowledgements}

The authors thank Rowl Twidale, Arthur Fuller, Chris Hawkesworth, Tim Partridge and Mike de Wit for their constructive comments, but take full responsibility any conclusions and errors.

\section{References}

Allsopp, H.L. and Hargreaves, R.B. (1985). Rb-Sr ages and palaeomagnetic data for some Angolan alkaline intrusives. Transactions of the Geological Society of South Africa, 88, 295-300

Armstrong, R.A., Bristow, J.W. and Cox, K.G. (1984). The Rooi Rand dyke swarm, southern Lebombo. Special Publication of the Geological Society of South Africa, 13, 77-86.

Brown, R.W., Rust, D.J., Summerfield, M.A., Gleadow, A.J.W. and de Wit, M.C.J. (1990). An early Cretaceous phase of accelerated erosion on the southwestern margin of Africa: evidence from apatite fission track analysis and the offshore sedimentary record. Nuclear Tracks and Radiation Measurements, 17, 339-350.

Burke, K. and Dewey, J. F. (1973). Plume generated triple junctions: key indicators in applying plate tectonics to old rocks. Journal of Geology, 81, 406-433.

Cox, K.G. (1989). The role of mantle plumes in the development of continental drainage patterns. Nature, 342, 873-877.

Cox, K.G. (1992). Karoo igneous activity and the early stages of the breakup of Gondwanaland. Geological Society Special Publication, 68, 137-148.

Cox, K.G. (1993). Continental magmatic underplating. Philosophical Transactions of the Royal Society of London, A342, 155-166.

Darracott, B.W. and Kleywegt, R.T. (1974). The structure of the southern portion of the Lebombo volcanic belt deduced from gravity data. Transactions of the Geological Society of South Africa, 77, 301-308. De Wit, M.C.J. (1999). Post-Gondwana drainage and the development of diamond placers in western South Africa. Economic Geology, 94, 721-740.

Dingle, R.V. Siesser, W.G. and Newton, A.R. (1983). Mesozoic and Tertiary history of southern Africa. A.A. Balkema, Rotterdam, The Netherlands, 375pp.

Du Toit, A.L. (1910). The evolution of the river system of Griqualand West. Transactions of the Royal Society of South Africa, 1, 347-361.

Eales, H. V., Marsh, J. S., and Cox, K.G. (1984). The Karoo igneous province: an introduction. Special Publication of the Geological Society of South Africa, 13, 1-26.
Ebinger, C., and Sleep, N. (1998). Cenozoic magmatism throughout East Africa resulting from impact of a single plume. Nature, 395-488.

Marsh, J.S. (1973). Relationships between transform directions and alkaline igneous rock lineaments in Africa and South America. Earth and Planetary Science Letters, 18 317-323.

Marsh, J.S., Hooper, P.R., Rehacek, J., Duncan, R.A. and Duncan, A.R. (1997). Stratigraphy and age of Karoo basalts of Lesotho and implications for correlations within the Karoo Igneous Province. American Geophysical Union Geophysical Monograph, 100, 247-271.

Moore, A.E. (1999). A reappraisal of epeirogenic flexure axes in southern Africa. South African Journal of Geology, 102, 363-376.

Moore, A.E and Larkin, P.A. (2001). Drainage evolution in south-central Africa since the break-up of Gondwana. South African Journal of Geology, 104, 47-68.

Nairn, A.E.M., Lerche, I. and Lliffe, J.E. (1991). Geology, basin analysis, and hydrocarbon potential of Mocambique and the Mocambique Channel. Earth Science Reviews, 30, 81-124.

O'Connor, J.M. and le Roux, A.P. (1992). South Atlantic hot spot - plume systems: 1. Distribution of volcanism in time and space. Earth and Planetary Science Letters, 113, 343-364.

Reeves, C.V. (1978). A failed Gondwana spreading axis in southern Africa. Nature, 273, 222-223

Reeves, C. (2000). The geophysical mapping of Mesozoic dyke swarms in southern Africa and their origin in the disruption of Gondwana. Journal of African Earth Science, 30, 499-513.

Sonaka, I.K. and Garda, G.M. (1988). Idades K-Ar de rochas alkalinas do Brasil Meridional e Paragui Oriental: compilaç_o e adaptaç_o às novas constants de decaimento. Bolletim do IG-USP, Seríe Cievtífica, 18, $359-362$

Stewart, K., Turner, S., Kelley, S., Hawkesworth, C., Kirstein, L. and Mantovani, M. (1996). 3D, ${ }^{40} \mathrm{Ar}-{ }^{39} \mathrm{Ar}$ geochronology in the Paraná continental flood basalt province. Earth and Planetary Science Letters, 143, 95-109.

Storey, B.C. and Kyle, P.R. (1997). An active mantle mechanism for Gondwana breakup. South African Journal of Geology, 100, 283-290.

Summerfield, M.A. (1990). Geomorphology and mantle plumes. Nature, 344, 387-388.

Summerfield, M. A. (1991). Global geomorphology. Longman Scientific and Technical, England, 537 pp.

Swanson, D.A., Wright, T.L. and Helz, R.T. (1975). Linear vent systems and estimated rates of magma production and eruption for theYakima basalt of the Columbia plateau. American Journal of Science, 275, 877-905.

Turner, S., Regelous, M., Kelley, S., Hawkesworth, C. and Mantovani, M. (1994). Magmatism and continental break-up in the south Atlantic: high precision ${ }^{40} \mathrm{Ar}-{ }^{39} \mathrm{Ar}$ geochronology. Earth and Planetary Science Letters, 121, 333-348.

Veevers, J.J., Cole, D.I. and Cowan, E.J. (1994). Southern Africa: Karoo basin and Cape fold belt. In: Veevers, J.J. and Powell, C.McA. (eds.), Permian-Triassic Pangean basins and foldbelts along the Panthalassan margin of Gondwanaland. Geological Society of America, Memoir, 184, 223-279.

Visser, J.N.J. (1987). The palaeogeography of part of southwestern Gondwana during the permo-carboniferous glaciation. Palaeogeography, Palaeoclimatology, Palaeoecology, 61, 205-219.

Wellington, J.H. (1955). South Africa - A Geographic Study, Vol. 1. Physical Geography. Cambridge University Press, UK, 528 pp.

White, R.S. (1997). Mantle plume origin for the Karoo and Ventersdorp flood basalts, South Africa. South African Journal of Geology, 100, 271-282.

White, R.S and Mckenzie, D.P. (1989) Magmatism at rift zones: The generation of volcanic continental margins and flood basalts. Journal of Geophysical Research, 94, 7685-7730.

White, S. H., de Brooder, H., and Smith, C. B. (1995). Structural controls of kimberlite and lamproite emplacement. Journal of Geochemical Exploration, 53, 245-264.

Editorial handling: J. M. Barton Jr. 